Vol. 17 (2008): 210-226.

\title{
Properties and cleanability of new and traditional agricultural surface materials
}

\author{
Jenni Määttä ${ }^{1}$, Hanna-Riitta Kymäläinen ${ }^{1}$, Maarit Hellstedt ${ }^{2}$, Riitta Mahlberg ${ }^{3}$, Risto Kuisma ${ }^{1}$, Liisa \\ Salparanta $^{3}$, Mia Löija ${ }^{3}$, Asaye Talibachew ${ }^{1}$, Kaj-Roger Hurme $^{4}$, Antti Uusi-Rauva ${ }^{4}$, \\ Anne-Christine Ritschkoff ${ }^{3}$ and Anna-Maija Sjöberg ${ }^{1 *}$ \\ ${ }^{1}$ Department of Agrotechnology, PO Box 28, FI-00014 University of Helsinki, Finland, \\ ${ }^{2}$ MTT Agrifood Research Finland, Animal Production Research, Vakolantie 55, FI-03400 Vihti, Finland \\ ${ }^{3}$ VTT Technical Research Centre of Finland, PO Box 1000, FI-02044 VTT, Finland \\ ${ }^{4}$ Isotope Department of Instrument Centre at Faculty of Agriculture and Forestry, PO Box 27, \\ FI-00014 University of Helsinki, Finland \\ *email:anna-maija.sjoberg@helsinki.fi
}

The aim of the present study was to evaluate new and traditional surface materials for use in cattle barns. The evaluated concrete materials had different compositions and included different additives and coatings. Contact angle meter, optical profilometry and scanning electron microscopy SEM were used for characterization of surface properties. Radiochemical methods and a biochemical adenosine triphosphate ATP method were used to determine cleanability. A specific methodological aim was to examine the correlations between these determination methods. A statistically significant difference was observed between contact angles of non-coated concretes, coated concretes and joint materials. In general, coatings smoothened surfaces and the joint materials were the roughest surfaces, as illustrated by profilometry and SEM. On the basis of the radiochemical determination methods, coatings improved the cleanability of concrete. An epoxy joint material was cleaned efficiently from the oil model soil and from the labelled feed soil when compared to the two cement-based joint materials. According to the results of the biochemical ATP method the manure test soil was cleaned better from a concrete including inorganic sealant than from the other materials examined. The cleanability results of oil model soil used in the radiochemical method correlated with the results of the test feed soil used in the biochemical ATP method. Both determination methods of cleanability appeared to be suitable for examining the cleanability of surfaces soiled with agricultural soils. Only the radiochemical determination gives detailed quantitative results, but it can be used only in laboratory studies. The results of this laboratory study will be used for selecting materials for a pilot study in a cattle barn.

Key-words: Cleanability, animal house, flooring, radiochemistry, gammaspectrometry, liquid scintillation counting, ATP, bioluminescence, SEM, contact angle

(C) Agricultural and Food Science

Manuscript received May 2007 
Vol. 17 (2008): 210-226.

\section{Introduction}

Material choices in agricultural environments affect animal welfare, hygienic condition of surfaces and products, and the working environment of the personnel. Many demands are applied to floorings in animal buildings. The flooring should withstand strong mechanical and chemical stresses, and when used in lying areas for animals it should also be comfortable to lie on. The flooring should not cause injuries, diseases, distress and discomfort or inconvenience to animals (Baxter 1984). The properties of the flooring materials which must be considered include e.g thermal comfort, softness, friction, abrasiveness and contact pressure between animal and floor (Nilsson 2005). The cleanability of surfaces is one aspect affecting the choice of flooring material for cattle barns. In general, a smooth flooring can be kept clean more easily than a rough flooring (Hörndahl 1995). However, when evaluating surface materials used in animal houses it should be remembered that surfaces which are too smooth may be slippery for animals and personnel, and cause injuries. The amount of soil and moisture on the flooring influence the floor properties; above all soil affects the slipperiness (Nilsson 2005).

Concrete is a very generally used floor material in agricultural buildings. Although concrete is a material which is often well suited for agricultural environment, it is far from being unaffected by many environmental hazards (Nilsson 2005). Animals and vehicles wear floorings mechanically, and feeds, milk and manure represent chemical hazards for concrete (Table 1).
According to De Belie et al. (2000) the durability of concrete against attack by lactic and acetic acids has been improved in many ways, e.g. by using different cement types and pozzolanic additives, changing the aggregate type, addition of polymers to the concrete mix, application of cement-bound surface layers and impregnation with water repellents or pore blockers or application of coatings. Coatings can be used to limit water penetration into concrete, which is a porous material. Substances soaked into reinforced concrete materials are the main reason for its disintegration (Barbucci et al. 1997).

In previous studies concerning the cleanability of animal houses, different evaluation methods such as visual (Sundahl 1974, Puumala and Lehtiniemi 1993, Hörndahl 1995, Larsson 2000, Zhang et al. 2006), microbiological and biochemical (Larsson 2000, Pelletier et al. 2002, Small et al. 2007) and optical methods (Zhang et al. 2006) were used. In the study by Kymäläinen et al. (2008), radiochemical and colorimetric methods were used for comparing the cleanability of concrete and plastic coatings for use in piggeries. Radiochemical methods have earlier been used for flooring materials in public buildings (Ohlson and Wäänänen 1971, Jokelainen and Uusi-Rauva 1976, Engström and Bäckström 1987, Pesonen-Leinonen et al. 2006, Määttä et al. 2007a). These methods provide quantitative information on the amount of soil both on the surface and soaked into the material. This capability is especially important when porous materials such as concrete are evaluated. The biochemical ATP method provides information on the biological contamination on surface. The ATP method has been used to determine

Table 1. Chemical substances and contaminants of concrete in cattle barns.

\begin{tabular}{llll}
\hline Source & Acid & Effect & Reference \\
\hline Silage & Lactic, acetic, butyric & Acids weaken slowly & ACI 515.1R-79 1985, Bertron et al. \\
& & Fresh milk harmless, fermented lactic & ACI 515.1R-79 1985 \\
Milk & Lactic & acid weakens slowly & \\
& & Acids weaken slowly & ACI 515.1R-79 1985, De Belie et al. \\
Manure & Acetic, propionic, butyric, & A & 1996, Bertron et al. 2005 \\
Urea & iso-butyric & Harmless for concrete & ACI 515.1R-79 1985
\end{tabular}

- not included 
Määttä, J. et al. Surface materials for use in cattle barns

the cleanability of surfaces from organic soils in the food industry and in public and hospital buildings (Poulis et al. 1993, Kuisma et al. 2003, Larson et al. 2003, Pesonen-Leinonen et al. 2003, Aycicek et al. 2006, Redsven et al. 2007).

The aim of the present study was to examine the surface properties and cleanability of new and traditional surface materials. The effects of different compositions and additives and coatings on the cleanability of concrete flooring were examined. The materials prepared and evaluated were intended for use in floorings and feeding tables in cattle barns. In addition, the cleanabilities of joint materials to be used with ceramic tiles e.g. in milk rooms were evaluated. Results from the laboratory studies will be used when selecting materials for a pilot study in a cattle barn.

\section{Materials and methods}

Radiochemical methods with three labelled model soils and two labelled natural soils were used for evaluating cleanability. In addition, a biochemical ATP method was used for assessing cleanability of the surfaces from organic soils. The surface properties were examined by determining water contact angles and surface roughness parameters.

\section{Laboratory-made and commercial surface materials}

The materials evaluated are presented in Tables 2 and 3. Epoxy, polyurethane, acrylic and polyester were used as surface coatings. The thicknesses of the coatings varied between $0.5 \mathrm{~mm}$ and $5 \mathrm{~mm}$. The basic cement paste was in some cases treated with fluosilicate or an inorganic sealant. Fluosilicate was brushed and soaked to the sandblasted sample surface, whereas inorganic sealant was brushed and sprayed on (Table 3). In addition, the cement paste without any coating or extra treatment was examined. In all experimental materials, the basic cement paste was laboratory-made, whereas commercial versions of the other materials were examined. However, not all the materials are used

Table 2. Codes and compositions of the evaluated surface materials and their possible use in cattle barns.

\begin{tabular}{|c|c|c|c|c|c|c|}
\hline \multirow{2}{*}{ Code } & \multicolumn{2}{|c|}{ Components } & \multirow{2}{*}{$\begin{array}{l}\text { Experimental material } \\
\text { (E) or material already } \\
\text { in use }(U)\end{array}$} & \multicolumn{3}{|c|}{ Site } \\
\hline & Substrate & Surface coating or treatment & & Floor & $\begin{array}{l}\text { Feeding } \\
\text { table }\end{array}$ & Joint \\
\hline $\mathrm{J} 1$ & Joint material, cement-based & None & $\mathrm{E}$ & - & - & $\mathrm{X}$ \\
\hline $\mathrm{J} 2$ & $\begin{array}{l}\text { Joint material with additives, } \\
\text { cement-based }\end{array}$ & Fluorochemical & $\mathrm{E}$ & - & - & $\mathrm{X}$ \\
\hline $\mathrm{J} 3$ & $\begin{array}{l}\text { Joint material, containing } \\
\text { epoxy }\end{array}$ & None & $\mathrm{U}$ & - & - & $\mathrm{X}$ \\
\hline $\mathrm{C} 1$ & Cement paste & Trowelled & $\mathrm{U}$ & $\mathrm{X}$ & $\mathrm{X}$ & - \\
\hline $\mathrm{C} 2$ & Cement paste & Fluosilicate & $\mathrm{U}$ & $\mathrm{X}$ & $\mathrm{X}$ & - \\
\hline $\mathrm{C} 3$ & Cement paste & Inorganic sealant & $\mathrm{E}$ & $\mathrm{X}$ & $\mathrm{X}$ & - \\
\hline Col & Fibre cement & Acrylic coating & $\mathrm{U}$ & $\mathrm{X}$ & $\mathrm{X}$ & - \\
\hline $\mathrm{Co} 2$ & Fibre cement & Polyurethane coating & $\mathrm{U}$ & $\mathrm{X}$ & $\mathrm{X}$ & - \\
\hline $\mathrm{Co} 3$ & Cement paste & Epoxy coating & $\mathrm{U}$ & $\mathrm{X}$ & $\mathrm{X}$ & - \\
\hline $\mathrm{Co} 4$ & Concrete & Polyester coating & $\mathrm{U}$ & - & $\mathrm{X}$ & - \\
\hline
\end{tabular}

-not suitable 
Vol. 17 (2008): 210-226.

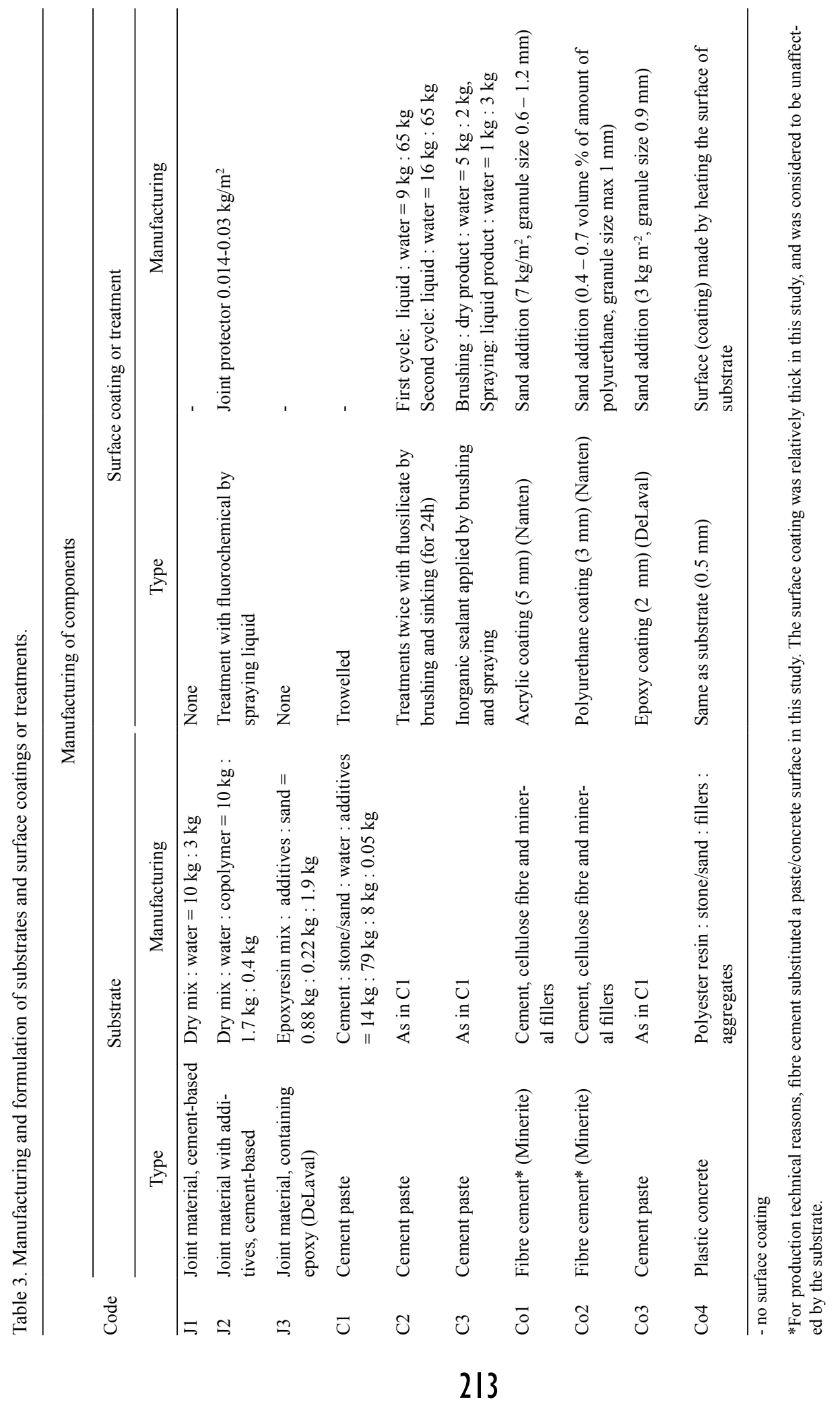


Määttä, J. et al. Surface materials for use in cattle barns

in animal houses or marketed for that use at present. Three different joint materials were also evaluated (Table 2). Two of them were cement-based clinker joint materials, one of which was treated by spraying with fluorochemical (Table 3). The third joint material was a commercial clinker joint material containing epoxy.

\section{Cleanability experiments and characteri- zation of surfaces}

The experimental design of determination of cleanability and surface properties is presented in Fig. 1. Two different radiochemical determination methods, a gammaspectrometric method and liquid scintillation counting, were used for evaluation of the cleanliness of the surfaces (Fig. $1)$. The radioactivity of a surface is comparable to the amount of labelled isotope on the surface. ATP bioluminescence is a rapid method for monitoring the cleanliness of surfaces (Fig. 1). The method is based on the hydrolysis of ATP by luciferase enzyme, detected by a luminometer and reported as relative light units (RLU). Surface properties were examined using a contact angle meter, an optical profilometer and a SEM.

\section{Soils}

Three model soils and two labelled natural soils were used in the radiochemical study (Table 4) and manure and feed soils were used in the biochemical ATP study. In order to obtain natural soils suitable for the cleanability experiments, manure and feed were mixed with purified water and other substances (Table 4). The amounts of the radiochemical model soils were the same as used in our earlier studies (Määttä et al. 2007a). The amounts of the natural soils were selected in order to assist dosage and according to the detection limit of the ATP method.

In the ATP study the manure the manure soil (soil 6) consisted of $30 \mathrm{~g}$ manure and $48 \mathrm{ml}$ water. The soil was collected from a cattle barn (Minkiö, Finland) in the summer of 2005 as a batch of 10 $\mathrm{kg}$, homogenised and divided into $10 \mathrm{~g}$ packages in small plastic bags and stored in a freezer. The

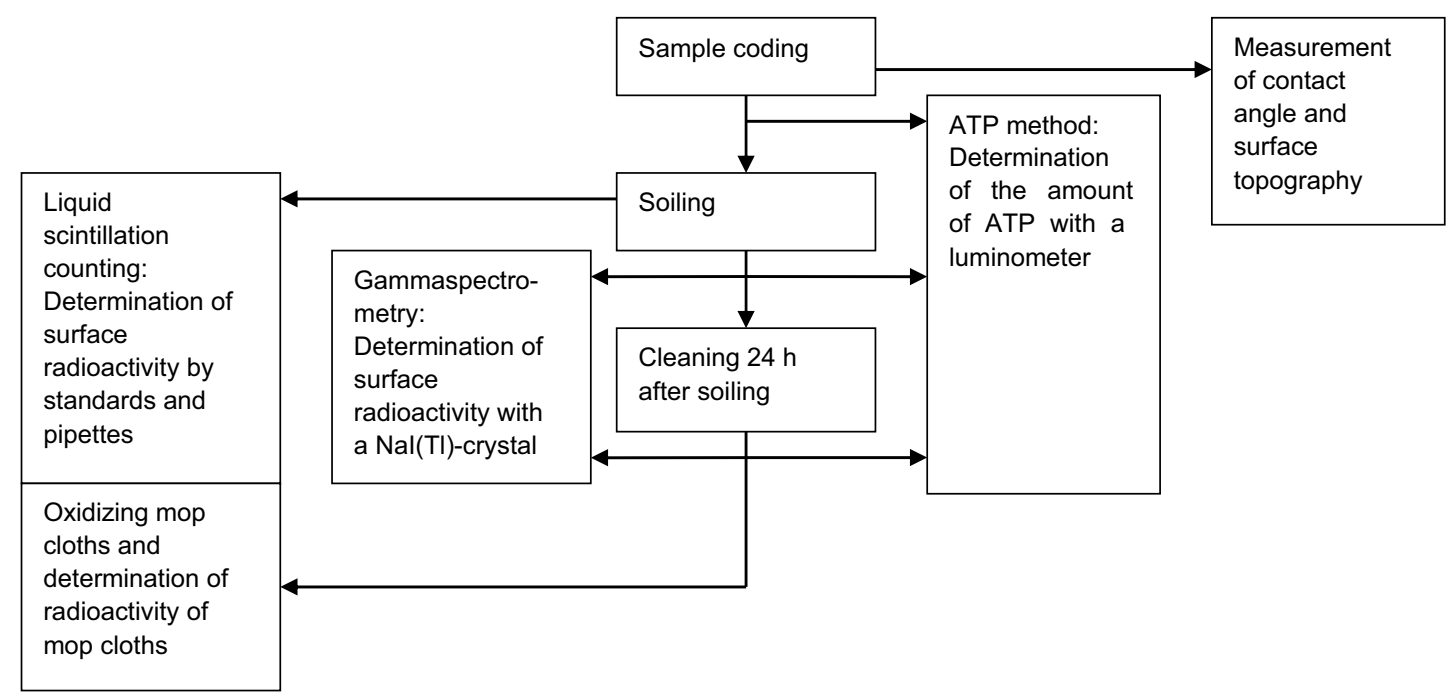

Fig. 1. Experimental design of the determination of cleanability and surface properties. 
Vol. 17 (2008): 210-226.

Table 4. Compositions and amounts of soils used in the radiochemical study. In radiochemical model soils, triolein refers to glyceryl trioleate.

\begin{tabular}{|c|c|c|c|c|c|c|}
\hline \multicolumn{2}{|c|}{ Type of the soil } & \multicolumn{4}{|c|}{ Components and their relative amounts ( $\mathrm{g}$ or $\mathrm{ml}$ ) of the soil mixtures } & \multirow{2}{*}{$\begin{array}{l}\text { Amount of } \\
\text { soil }(\mu 1) \text { on } \\
\text { a disc }\end{array}$} \\
\hline & & Chromium component & Solvent & $\begin{array}{l}\text { Other components } \\
\text { or substances }\end{array}$ & $\begin{array}{l}\text { Radio- } \\
\text { isotope }\end{array}$ & \\
\hline 1 & $\begin{array}{l}\text { Inorganic } \\
\text { particle } \\
\text { model soil }\end{array}$ & $\begin{array}{l}\text { Chromium (III) oxide } \\
\left(\mathrm{Cr}_{2} \mathrm{O}_{3}\right)(\mathrm{m}=0.40 \mathrm{~g})\end{array}$ & $\begin{array}{l}\text { 1-propanol } \\
(\mathrm{V}=10 \mathrm{ml})\end{array}$ & $\begin{array}{c}\text { Triolein } \\
\left(\mathrm{C}_{57} \mathrm{H}_{104} \mathrm{O}_{6}\right) \\
(0.60 \mathrm{ml})\end{array}$ & ${ }^{51} \mathrm{Cr}$ & 50 \\
\hline 2 & $\begin{array}{l}\text { Organic } \\
\text { particle } \\
\text { model soil }\end{array}$ & $\begin{array}{l}\text { Chromium acetyl acetonate } \\
\left(\mathrm{C}_{15} \mathrm{H}_{21} \mathrm{CrO}_{6}\right)(\mathrm{m}=0.40 \mathrm{~g})\end{array}$ & $\begin{array}{l}\text { 1-propanol } \\
(\mathrm{V}=10 \mathrm{ml})\end{array}$ & $\begin{array}{c}\text { Triolein } \\
\left(\mathrm{C}_{57} \mathrm{H}_{104} \mathrm{O}_{6}\right) \\
(0.60 \mathrm{ml})\end{array}$ & ${ }^{51} \mathrm{Cr}$ & 50 \\
\hline 3 & $\begin{array}{l}\text { Organic oil } \\
\text { model soil }\end{array}$ & $\begin{array}{l}\text { Chromium (III) oxide } \\
\left(\mathrm{Cr}_{2} \mathrm{O}_{3}\right)(\mathrm{m}=0.40 \mathrm{~g})\end{array}$ & $\begin{array}{l}\text { 1-propanol } \\
(\mathrm{V}=10 \mathrm{ml})\end{array}$ & $\begin{array}{c}\text { Triolein } \\
\left(\mathrm{C}_{57} \mathrm{H}_{104} \mathrm{O}_{6}\right) \\
(0.60 \mathrm{ml})\end{array}$ & ${ }^{14} \mathrm{C}$ & 50 \\
\hline 4 & $\begin{array}{l}\text { Labelled } \\
\text { manure soil }\end{array}$ & $\begin{array}{l}\text { Chromium (III) oxide } \\
\left(\mathrm{Cr}_{2} \mathrm{O}_{3}\right)(\mathrm{m}=0.15 \mathrm{~g})\end{array}$ & $\begin{array}{c}\text { Water } \\
(\mathrm{V}=16 \mathrm{ml})\end{array}$ & $\begin{array}{l}\text { Manure } \\
(\mathrm{m}=10 \mathrm{~g})\end{array}$ & ${ }^{51} \mathrm{Cr}$ & 625 \\
\hline 5 & $\begin{array}{l}\text { Labelled } \\
\text { feed soil }\end{array}$ & $\begin{array}{l}\text { Chromium (III) oxide } \\
\left(\mathrm{Cr}_{2} \mathrm{O}_{3}\right)(\mathrm{m}=0.15 \mathrm{~g})\end{array}$ & $\begin{array}{c}\text { Water } \\
(\mathrm{V}=16 \mathrm{ml})\end{array}$ & $\begin{array}{c}\text { Feed } \\
(\mathrm{m}=5 \mathrm{~g})\end{array}$ & ${ }^{51} \mathrm{Cr}$ & 625 \\
\hline
\end{tabular}

composition of the manure soil was measured at Novalab Oy (Finland) using a gravimetric method for raw food fat and a Kjeldahl method for protein, and the amounts of carbohydrates, dry matter and ash were calculated. Manure consisted of dry matter $(16.5 \%)$, combustible/matter ash $(2.8 \%)$, raw food fat $(1.5 \%)$, protein $(2.9 \%)$ and carbohydrates (9.3\%).

In the ATP study the feed soil (soil 7) consisted of $15 \mathrm{~g}$ feed and $48 \mathrm{ml}$ water. The soil was a dry milk-based feed product, produced by Raisio Feed Ltd and intended for feeding of calves. According to information provided by the manufacturer, the composition of the feed was: moisture (12.5\%), raw food fat $(4.7 \%)$, crude protein $(18.3 \%)$, raw fibre $(5.3 \%)$, combustible remains $(8.2 \%)$, calcium (1.1\%), phosphorus $(0.7 \%)$, magnesium $(0.4 \%)$ and sodium $(0.4 \%)$. The feed was stored at room temperature in a paper sack.

Inorganic particle and oil model soils were labelled both with the gamma-ray emitter ${ }^{51} \mathrm{Cr}$ and the beta-ray emitter ${ }^{14} \mathrm{C}$ and organic particle model soil was labelled with ${ }^{51} \mathrm{Cr}$. Natural manure and feed soils were also labelled with ${ }^{51} \mathrm{Cr}$ when used as ra- diochemical soils. The cleanabilities of different components of model soils can be determined by measuring the different radio-isotopes. In this study the ${ }^{51} \mathrm{Cr}$ isotope labelled particle components and the ${ }^{14} \mathrm{C}$ isotopes labelled the oil component.

\section{Soiling and cleaning for the radiochemical method}

Soiling with the radiochemical model soils was carried out with the procedure described earlier by Pesonen-Leinonen et al. (2006) and Määttä et al. (2007a) (Fig. 1). The samples were subjected to one soiling and cleaning cycle. The fluid model soils $(50 \mu \mathrm{l})$ were applied to the middle of the sample (size $3 \mathrm{~cm} \times 3 \mathrm{~cm}$ ) with a pipette and 1-propanol was used as a carrier to assist dosage (Table 4). The natural soils $(625 \mu \mathrm{l})$ were applied to the sample with a measure and deionised water was used to assist the dosage. The soils were left to dry for 24 $\pm 2 \mathrm{~h}$ at room temperature. Cleaning was carried out with a Mini Cleanability Tester (Pesonen-Leinonen 


\section{AGRICULTURAL AND FOOD SCIENCE}

\section{Määttä, J. et al. Surface materials for use in cattle barns}

et al. 2006, Määttä et al. 2007a,b). The estimated pressure applied to the sample was $25 \mathrm{kPa}$, velocity $30 \mathrm{rpm}$ and the number of revolutions was three. The cleaning head was equipped with a microfibre cloth (Freudenberg Household Products Oy Ab) (Pesonen-Leinonen et al. 2003, 2006, Määttä et al. $2007 a, b)$. The material of the microfibre cloth was polyester (100\%) and the pile length was $8 \mathrm{~mm}$. The microfibre material is not used for cleaning cattle barns but was a part of the radiochemical method. For cleaning model soils the cloth was moistened at $100 \%$ weight regain compared to the weight of the dry cloth, with a 5\% weakly alkaline detergent solution (Kuisma et al. 2005, Pesonen-Leinonen et al. 2006) and to clean natural soils the moisture regain was $200 \%$.

\section{Measurement of cleanability using the radiochemical method}

The radioactivity of the surface was a measure of the amount of the labelled component of soil on the sample. In this study we measured the removal of soil by measuring soil residues. Soil residue indicates how much soil remains on the surface after cleaning. The cleaning result was presented as the proportion of the labelled component of soil after cleaning compared to that after soiling. Five replicate tests were performed for each test combination.

The cleanabilities of the natural soils and model soils labelled with the gamma-ray emitter ${ }^{51} \mathrm{Cr}$ ( Table 4) were determined by a gammaspectrometric method using an $\mathrm{NaI}(\mathrm{Tl})$-scintillation crystal (Fig. 1). The counting system is composed of a 2 " $\times 2$ " $\mathrm{NaI}(\mathrm{Tl})$-crystal detector (Bicron Corporation, Ohio, USA), coupled to a multichannel analyser and standard electronics (Canberra Inc., Connecticut, USA). The number of counts was recorded from 1 min to 5 min depending on the activity of the sample. The results were reported as counts per minute (cpm). The radioactivities of the soiled samples were measured before and after cleaning. The results were calculated by subtracting the activity of the background and correcting the results for radioactive decay.
The cleanability of model soil labelled with the beta-ray emitter ${ }^{14} \mathrm{C}$ (Table 4) was measured using liquid scintillation counting (Fig. 1). When preparing samples for measurement after cleaning, the concrete materials were too hard to be cut into pieces small enough without loosening activity, as reported in our earlier study on ceramic tiles (Määttä et al. 2007b). Therefore the activities of the mop cloths were measured in this case and the activities of the surface materials were calculated using these results. The mop cloths were oxidized in an oxidizer (Maricont 781, Junitek, Finland), radiolabelled carbon dioxide was trapped in a trapping agent and the radioactivity was measured with a liquid scintillation counter (Wallac 1411 Liquid Scintillation Counter, Wallac, Finland) and a measuring program $\left(1414\right.$ WinSpectral $\left.^{\mathrm{TM}}\right)$. The measurement time was $10 \mathrm{~min}$. The results were reported as disintegrations per minute (dpm). The radioactivities of materials after soiling were determined using five dosages of soil. Calculation of the results included the attenuation equalizer and subtraction of the background. Correction for radioactive decay was not needed because of the long half-life of carbon.

\section{Soiling and cleaning for the biochemical ATP method}

In order to prepare experimental soils suitable for spreading on the surface material samples, the basic manure and feed soils were mixed with purified MilliQ water. The soils were prepared by pouring the soil and pipetting the water into a plastic bag (Stomacher Lab Systems Model 400 Bags, Seward Limited, UK) The mixture was allowed to stabilize for 30 min and homogenized in a Stomacher Circulator 400 (Seward Limited, UK) at $230 \mathrm{rpm}$ for $5 \mathrm{~min}$. Part $(0.5 \mathrm{~g})$ of the soil mixture thus obtained was applied to the sample (on an area of approximately $10 \mathrm{~cm}^{2}$ in the middle of the surface sample) with a measure. The soils were left to dry for $24 \pm 2 \mathrm{~h}$ at room temperature (Fig. 1).

Cleaning was carried out with the Erichsen Washability and Scrubbing Resistance Tester, model 494 (Erichsen GMBH and Co, Germany) 
Vol. 17 (2008): 210-226.

using the same microfibre mop cloth as in the radiochemical experiments. The cloth was moistened to $100 \%$ moisture regain with MilliQ water (no detergent was used). The surroundings of the sample to be tested were covered with plastic film to prevent cross contamination of the Erichsen machine and its parts. The surface samples were cleaned by moving the cleaning cloth back and forth across the sample. Five washing cycles were selected to represent approximately equal possible real cleaning practices. The estimated pressure applied to the sample was $1.4 \mathrm{kPa}$. Five replicate tests were performed for both soils.

\section{Measurement of cleanability using the biochemical ATP method}

ATP samples from the soiled surfaces were taken with sterile cotton swabs from an area of approximately $10 \mathrm{~cm}^{2}$. The procedure was carried out according to the manufacturer's instructions. The ATP bioluminescence was measured luminometrically with the HY-LiTE ${ }^{\circledR} 2$ equipment (Merck KgaA, Germany). The intensity of light thus generated was read as relative light units (RLU). RLU is directly related to the amount of ATP and thus to the organic contamination on the surface. The samples were evaluated three times: before and after soiling and after cleaning (Fig. 1). The ATP amount of the samples before soiling was evaluated from five separate samples, the mean of which was used as a basic value for both soil cases.

\section{Contact angle measurements}

Repellence properties of the materials were evaluated by measuring contact angles using a CAM 100 contact angle meter (KSV Instruments Ltd, Finland). The contact angle of water was used to assess the hydrophobicity or hydrophilicity of materials. Static water contact angles on the experimental surfaces before soiling were measured. A water drop (MilliQ water) was placed on the surface and imaged for 40 seconds, collecting one image per second (Määttä et al. 2007a). The contact angles were presented as the mean of the last twenty images. Calculation of contact angle was based on the Young-Laplace equation. The result was the mean of the drop of five replicate samples. The sessile drop technique has earlier been used for concrete materials by Benzarti et al. (2006).

\section{Topography assessment}

Surface features and roughness parameters of the material surfaces were imaged and measured by means of an optical profiler provided with 2D and 3D imaging capabilities (Sensofar Pl $\mu$ 2300). The material surfaces were imaged with $20 \times$ and $50 \times$ magnification. The measuring area was 0.64 $\times 0.48 \mathrm{~mm}^{2}$ in the magnification $20 \times$ and $0.25 \times$ $0.19 \mathrm{~mm}^{2}$ in the magnification $50 \times$. One image at each magnification was recorded and from each image five line profiles were measured. The $\mathrm{R}_{\mathrm{a}}$ roughness values (the arithmetical mean deviation of the profile) were derived from the line profiles. In addition, images of the surfaces were taken using a SEM (JEOL JSM-840, USA) at 100×, 500× and $1500 \times$ magnifications. The magnification $500 \times$ illustrated the surface best and was used for each material.

\section{Statistical methods}

Statistical analyses were performed using SPSS version 12.0 (SPSS Inc., Chicago IL, USA), based on the mean values of the results. The cleanability results for each of the soils were analysed separately. The cleaning result in the radiochemical method was presented as the proportion of the soil residue after cleaning compared to the amount of soil on the surface after soiling. The cleaning results of the biochemical ATP method were presented as RLUvalues before and after soiling and after cleaning. Analysis of variance was used to examine differences between the materials and treatments. Bivariate cor- 


\section{AGRICULTURAL AND FOOD SCIENCE}

\section{Määttä, J. et al. Surface materials for use in cattle barns}

relation analysis (Pearson's correlation coefficients, two-tailed test of significance) was used to examine possible correlations between roughness values, contact angles and soil residues. The significance used was 0.05 in analysis of variance and 0.01 in analysis of correlation.

\section{Results}

\section{Cleanability of the materials}

The soil residues of radiochemical model soils of all the samples are presented in Fig. 2. The soil residues of the radiochemically labelled manure and feed soils (soils 4 and 5, respectively) were at the same level in the case of non-coated concretes and joint materials. On the plastic coatings the residues of labelled feed soil were lower than those of labelled manure. In accordance with this result, the coatings improved the cleanability of surfaces from labelled feed soil ( $p=0.021$ in the analysis of variance) but not from labelled manure soil ( $p=0.412)$. In the case of simple model soils the soil residues of inorganic model soil 1 (chromium oxide and triolein labelled with ${ }^{51} \mathrm{Cr}$ ) were the lowest (except for J3) and in general the soil residues of organic oil model soil 3 (chromium oxide and triolein labelled with ${ }^{14} \mathrm{C}$ ) were the highest. According to soil residues, the coating improved the cleanability of concrete surfaces from oil model soil (Fig. 2) $(p=0.001)$. In general the soil residues of the organic model soil (soil 2, chromium acetyl acetonate and triolein labelled with ${ }^{51} \mathrm{Cr}$ ) were at the same level as the soil residues of both labelled natural soils, but no statistically significant correlations were observed.

According to the cleanability results of the radiochemical study, polyester (Co4), acrylic (Co1) and polyurethane ( $\mathrm{Co} 2)$ coatings improved cleanability the most efficiently, whereas the cleanabilities of the non-coated concretes were the lowest (Table 5). Interestingly, the cleanability of noncoated concrete including inorganic sealant (C3) from manure soil (labelled ${ }^{51} \mathrm{Cr}$ ) was better than that of coated concretes. According to the results in Table 5 the epoxy-coated concrete ( $\mathrm{Co} 3$ ) was cleaned most efficiently from the labelled natural soils in the radiochemical study.

The cleanability of epoxy-based joint differed from that of the cement-based joint materials. The epoxy joint was cleaned more efficiently from radiochemical oil model soil than the other joint materials, whereas the two cement joints were better cleaned from the other radiochemical model soils (Fig. 2).

The ATP content of the manure soil was clearly greater on surfaces after soiling than that of the feed soil. Most of the surfaces soiled with the manure soil had a mean ATP content between 2500 RLU and 7000 RLU, whereas the mean ATP content of the surfaces soiled with the feed soil was below 200 RLU. As an exception, the surface C3

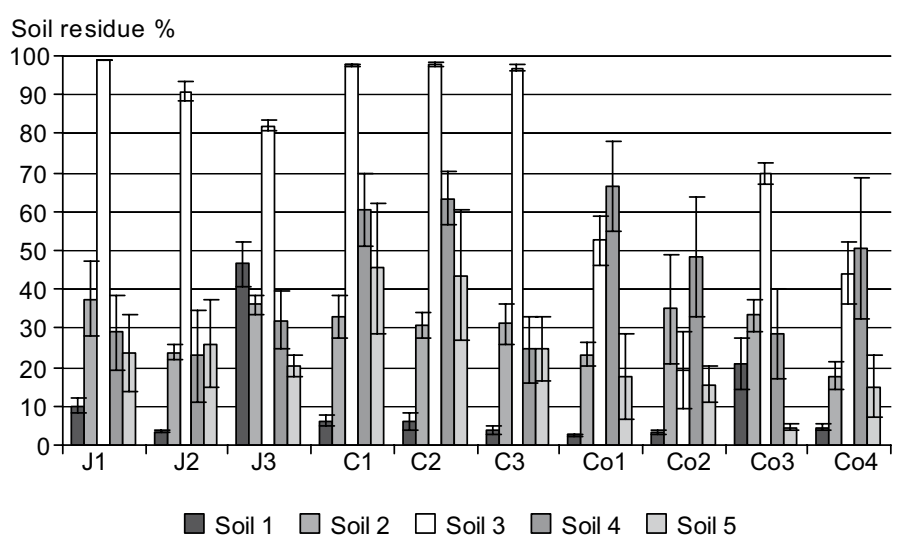

Fig. 2. Cleanability of the surfaces from five different soils as estimated by radiochemical measurements. The results are expressed as means (columns) and standard errors of means $( \pm$ SE, bar) of five replicates. The lower the soil residue, the better is the cleanability result. The codes of the samples are presented in Table 2 and the codes of the soils in Table 4. 
Vol. 17 (2008): 210-226.

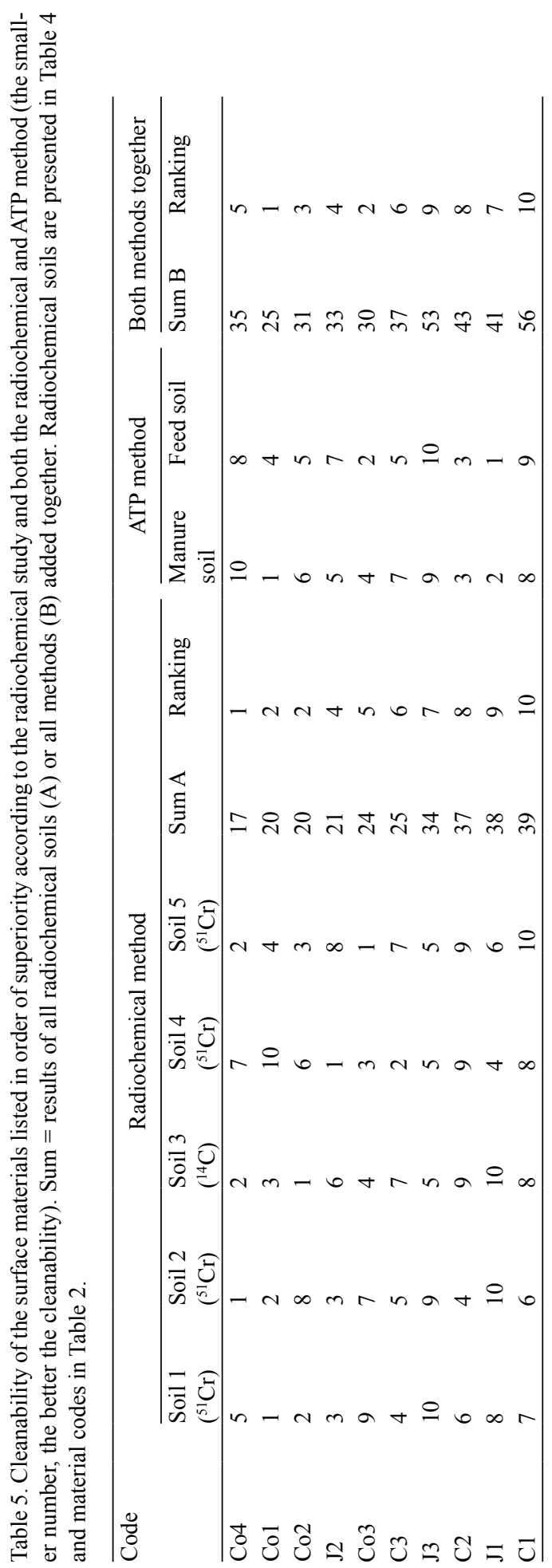

was relatively repellent to the manure soil (402 RLU in average).

In the biochemical ATP method, the first cleaning cycle removed a significant part of the manure soil from all surfaces (Fig. 3), but except the material C3 did not lead to the cleanness level of the unsoiled surfaces (Fig. 3). All materials except C3 behaved similarly. In removal of the manure soil, the second cleaning cycle decreased the ATP content of the surfaces approximately to the same level as before soiling. The ATP content of the surfaces soiled with the feed soil decreased after the first cleaning cycle to the same level as before soiling or even lower (Fig. 3). Material differences were negligible. In accordance with these results, there was a significant correlation between the ATP amounts of manure and feed soils after the second cleaning cycles $(r=0.811)$. In addition the ATP amount of feed soil after the first cleaning cycle correlated significantly with the soil residues of radiochemical model soil 3 (chromium oxide and triolein labelled with $\left.{ }^{14} \mathrm{C}\right)(\mathrm{r}=-0.639)$.

When surfaces were divided into three groups (non-coated concretes, coated concretes and joint materials) the surface type was found to affect the cleanability of radiochemical oil model soil (soil $3, p=0.004$ ), feed soil labelled with ${ }^{51} \mathrm{Cr}$ (soil 5, $p$ $=0.010)$ and the ATP amount of manure after the first cleaning (soil 7, $p=0.031$ ).

\section{Contact angles}

The contact angles of water in the surfaces varied between $19^{\circ}$ and $84^{\circ}$ (Table 6). The variation in contact angle values was wide due to the different compositions of materials. Surface type affected the water contact angles ( $p=0.050$ in comparison between non-coated concretes, coated concretes and joint materials). The contact angles of $\mathrm{C} 2$ and $\mathrm{J} 3$ were the lowest and those of $\mathrm{Co} 4$ the highest. Materials $\mathrm{C} 1$ and $\mathrm{C} 3$ were such porous materials that contact angles could not be measured. Water was rapidly absorbed into these surfaces. No statistically significant correlations between contact angles and soil residues were observed. 


\section{AGRICULTURAL AND FOOD SCIENCE}

Määttä, J. et al. Surface materials for use in cattle barns

Fig. 3. ATP contents of the surface materials before soiling and after cleaning from manure and feed soils with two cleaning cycles. Results are means (columns) and standard errors of means ( \pm SE, bar) of five replicates. The lower the soil residue, the better is the cleanability result. The codes of the samples are presented in Table 2 .

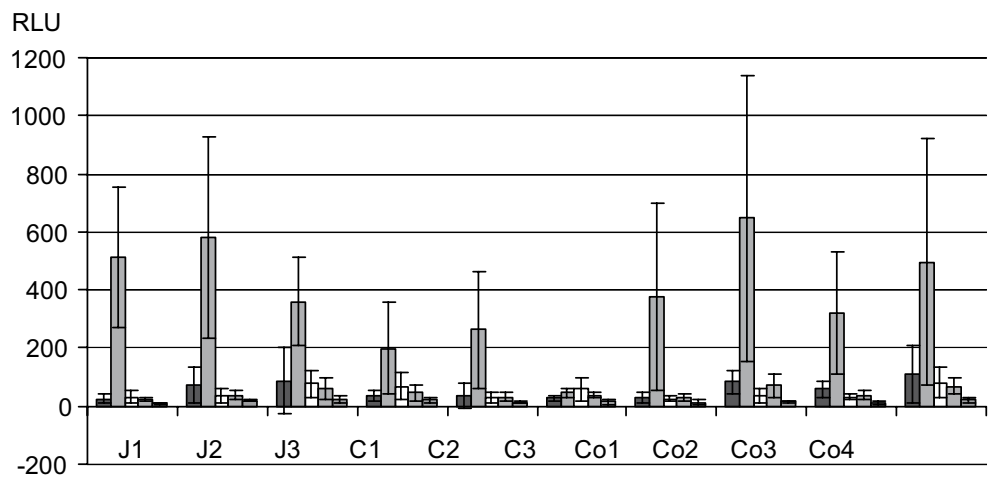

$\square$ Before soiling $\square$ Manure soil, after 1st cleaning $\square$ Manure soil, after 2nd cleaning $\square$ Feed soil, after 1st cleaning

Table 6. Determined contact angles and roughness parameters as means and standard deviations (SE). Sample codes are presented in Table 2.

\begin{tabular}{|c|c|c|c|c|c|c|}
\hline \multirow[t]{3}{*}{ Code } & \multirow{2}{*}{\multicolumn{2}{|c|}{$\begin{array}{l}\text { Contact angles } \\
\left({ }^{\circ}\right)\end{array}$}} & \multicolumn{4}{|c|}{$\begin{array}{c}\text { Roughness parameter } \mathrm{Ra}(\mu \mathrm{m}) \\
\text { Magnification }\end{array}$} \\
\hline & & & \multicolumn{2}{|c|}{$20 \times$} & \multicolumn{2}{|c|}{$50 \times$} \\
\hline & Mean & $\mathrm{SE}(\mathrm{n}=5)$ & Mean & $\operatorname{SE}(n=5)$ & Mean & $\mathrm{SE}(\mathrm{n}=5)$ \\
\hline $\mathrm{J} 1$ & 64 & 1 & 1.8 & 0.2 & 4.4 & 0.4 \\
\hline $\mathrm{J} 2$ & 78 & 2 & 1.0 & 0.2 & 10.5 & 0.8 \\
\hline $\mathrm{J} 3$ & 46 & 2 & 3.3 & 0.3 & 7.7 & 0.6 \\
\hline $\mathrm{C} 1$ & - & - & 2.1 & 0.1 & 5.0 & 0.2 \\
\hline $\mathrm{C} 2$ & 19 & 1 & 1.5 & 0.03 & 1.1 & 0.02 \\
\hline $\mathrm{C} 3$ & - & - & 3.0 & 0.1 & 2.3 & 0.2 \\
\hline Co1 & 63 & 2 & 0.9 & 0.06 & 0.4 & 0.01 \\
\hline $\mathrm{Co} 2$ & 65 & 2 & 0.2 & 0.04 & 0.5 & 0.05 \\
\hline $\mathrm{Co} 3$ & 63 & 3 & 2.2 & 0.3 & 0.7 & 0.08 \\
\hline $\mathrm{Co} 4$ & 84 & 2 & 3.7 & 0.1 & 1.8 & 0.3 \\
\hline
\end{tabular}

- no result obtained due to porous surface

\section{Topography}

The linear profiles were calculated from magnifications $20 \times$ and $50 \times$ (Table 6 ). In the case of the $50 \times$ magnification $\mathrm{Co} 1, \mathrm{Co} 2$ and $\mathrm{Co} 3$ were the smoothest surfaces and $\mathrm{J} 2, \mathrm{~J} 3$ and $\mathrm{C} 1$ the roughest ones. The roughness parameters $\mathrm{R}_{\mathrm{a}}$ varied between 0.39 and $10.47 \mu \mathrm{m}$. In the case of $20 \times$ magnification Co1, $\mathrm{Co} 2$ and $\mathrm{J} 2$ were the smoothest and $\mathrm{Co} 4, \mathrm{~J} 3$ and $\mathrm{C} 3$ the roughest. The roughness parameters $R_{a}$ varied between 0.18 and $3.70 \mu \mathrm{m}$. The $\mathrm{R}_{\mathrm{a}}$-values of $20 \times$ magnification correlated significantly with the ATP amount of manure soil after the second cleaning cycle (Pearson's correlation coefficient $r=0.794$ ). There were also statistically significant differences between the $\mathrm{R}_{\mathrm{a}}$-values of the three material groups 


\section{AGRICULTURAL AND FOOD SCIENCE}

Vol. 17 (2008): 210-226.

in the case of $50 \times$ magnification ( $p=0.044)$. However, no other correlations were observed between surface properties and soil residues.

Qualitative SEM micrographs of different types of surface materials are presented in Fig. 4 and 5. The most typical images were selected from the replicate measurements of magnification at $500 \times$. The cement-based joint material (J1) and cement paste, trowelled surface $(\mathrm{C} 1)$ were porous and uneven (Fig. 4a,d). On the cement-based joint material with additives (J2) there were cracks, which might have affected the cleaning of this surface (Fig. 5b). The commercial clinker joint material (J3) was uneven, with crystals on the surface (Fig. $4 \mathrm{c})$. The treated cement pastes $(\mathrm{C} 2$ and $\mathrm{C} 3)$ were rougher than most of the plastic coatings (Fig. 4e,f, Table 6) but smoother than the untreated cement paste (C1) (Fig. 4d). The acrylic-coated cement paste surface (Co1) was smooth (Fig. 5a and Table
6). The polyurethane- and epoxy-coated surface materials ( $\mathrm{Co} 2$ and $\mathrm{Co} 3)$ were also rather smooth, whereas the surface of the polyester coating $(\mathrm{Co} 4)$ was somewhat uneven and rough (Fig. 5b,c,d).

\section{Discussion}

In the experimental design of the study several methods from other fields of material research were implemented. This is important since there were only few previous studies available concerning surface materials and research methods in the cattle barn environment.

According to the present radiochemical study, coating improved the cleanability of materials, which is in accordance with previous studies by

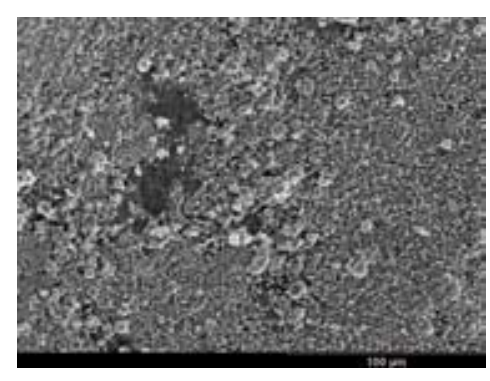

a) Cement-based joint material (J1)

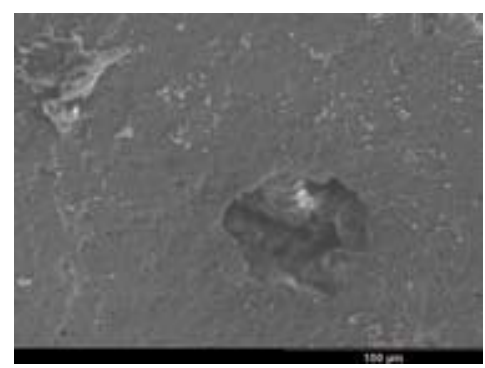

d) Cement paste, trowelled surface (C1)

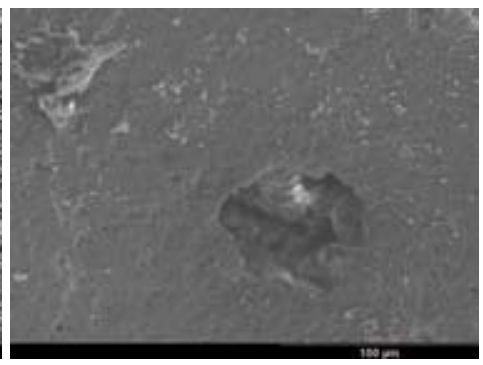

b) Cement-based joint material with additives (J2)

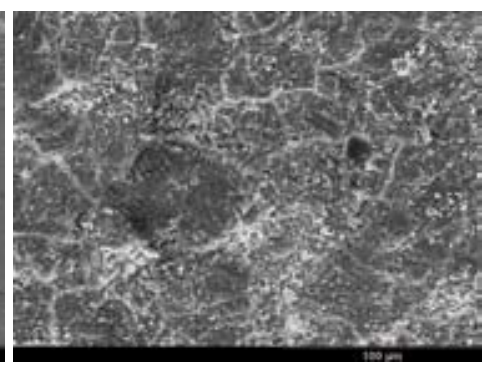

e) Cement paste with fluosilicate (C2)

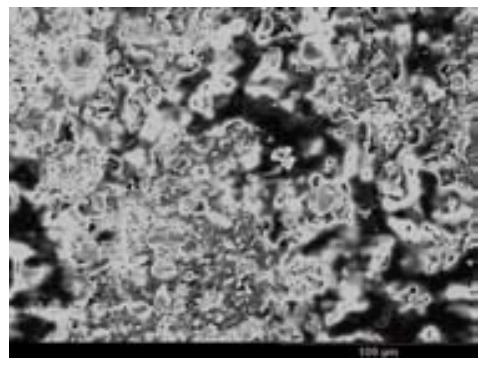

c) Clinker joint material, with additives (J2) epoxy (J3)

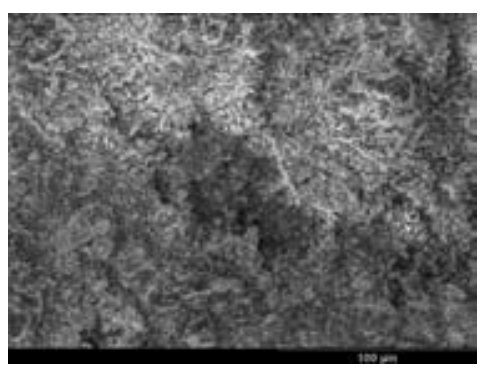

f) Cement paste with inorganic sealant (C3)

Fig. 4. SEM micrographs of surface materials (a-f), magnification $500 \times$. The codes of surface materials are given in Table 2 . 
Määttä, J. et al. Surface materials for use in cattle barns

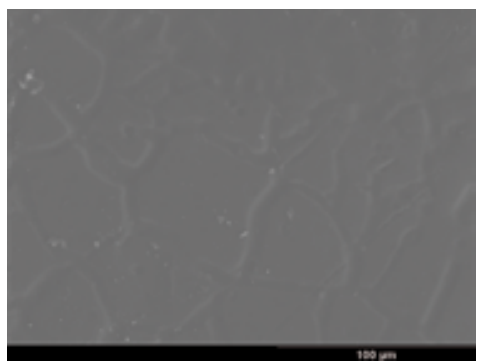

a) Cement paste acrylic coating (Co1)

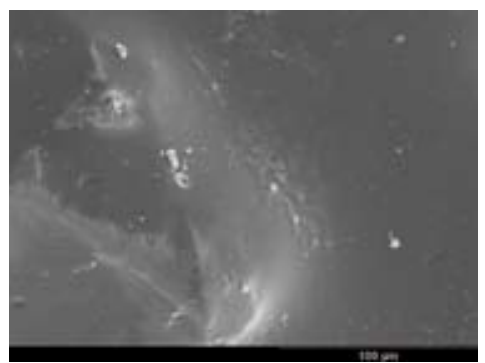

c) Cement paste epoxy coating (Co3)

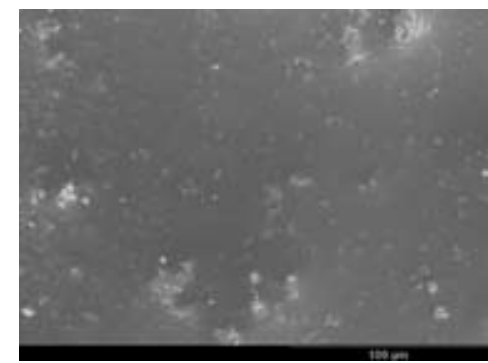

b) Cement paste polyurethane coating $(\mathrm{Co} 2)$

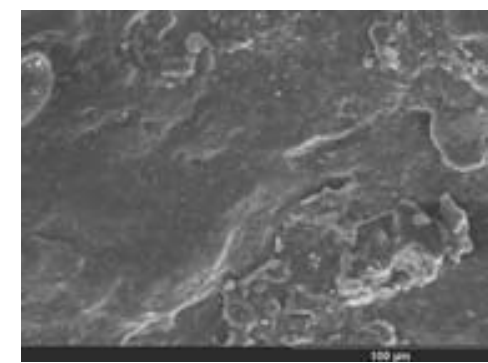

d) Concrete polyester coating ( $\mathrm{Co} 4)$
Fig. 5. SEM micrographs of surface materials (a-d), magnification $500 \times$. The codes of surface materials are given in Table 2 .
Puumala and Lehtiniemi (1993) and Kymäläinen et al. (2007). The cleanabilities from radiochemical oil model soil and labelled feed soil were both improved by coatings but no statistically significant correlations were observed, probably due to the wide variation of compositions of materials. However, the ATP amount of feed soil correlated statistically significantly with the soil residues of radiochemical oil model soil. Due to improved cleanability it is justified to use coatings where a good hygienic level is needed in cattle barns. The ATP method is a sensitive method and is valuable in the evaluation of hygienic level with nonvisible soils. This was illustrated in the present study in the cases when cleaned sample surfaces looked clean (e.g. samples Co1, C2, Co4) but had high ATP levels, or looked dirty (e.g. samples J1, J3, C3) but had a relatively low ATP content. The ATP method has limitations compared with the radiochemical methods, since although the manure soil was spread well on most samples, it was absorbed into some porous surfaces, e.g. samples $\mathrm{C} 1, \mathrm{C} 2$ and $\mathrm{Co} 2$.

In a study by Kemppainen et al. (2002), epoxy as an additive improved the cleanability of joint materials from a sebum (fat)-based model soil. In accordance with this result, in our study the epoxy joint was cleaned most efficiently from oil model soil, although the cleanabilities of other model soils were poorer than those of other joint materials. This is probably due to the lower contact angle of epoxy joint. The contact angles of the non-coated concrete materials were hard to measure due to rapid absorption of water into the surface. The samples coded $\mathrm{C} 1$ and $\mathrm{C} 3$ could not be measured. The concrete was probably so porous that the liquid soaked into it directly. Coatings probably filled the holes of surfaces, and due to this they became more sealed.

The variation of roughness parameters was relatively high, coated surfaces being smoother than non-coated concretes. There were differences 
Vol. 17 (2008): 210-226.

between roughness values of $20 \times$ and $50 \times$ magnification. This is probably due to the different measuring areas. The $50 \times$ magnification illustrated more the micro structure of the surface, whereas $20 \times$ magnification illustrated the macro structure. The smoothing effect of coating was shown in the SEM-figures.

Radiochemical determination methods have earlier been used to evaluate cleanability of PVC model materials and ceramic tiles (Pesonen-Leinonen et al. 2006, Määttä et al. 2007a, 2007b). Except in the study by Kymäläinen et al. (2008), such determination methods have not earlier been used to evaluate concrete materials. The radiochemical inorganic model soil (soil 1) was removed more efficiently from surfaces than radiochemical organic particle or oil model soils (soils 2 and 3). The radiochemical model soils did not correlate with the radio labelled natural soils. The model soils are labelled to model one component of soil, whereas the present real soils were more complex, containing various components. The use of model soils provides detailed information concerning individual soil components, but according to this study it cannot be used to simulate natural agricultural soils. There is no previous published information concerning the use of isotope labelling with manure or feed soil. In the case of radio labelled natural soils, the results concern the labelled isotope in manure or feed mixture, but indicate the behaviour of the whole soil mixture. From the practical point of view, addition of isotope to the bulk soil was the only way to label the manure and feed soil in this study. However, in our earlier study radiochemical model soils correlated with manure soil when the cleanability was determined by colorimetry (Kymäläinen et al. 2008). In the present study correspondence was observed between radiochemical oil model soil and the ATP amount of feed soil after the first cleaning cycle.

There is no previous published information concerning use of the ATP method with manure or feed soil. Since both microbial and non-microbial (somatic) cells contain ATP and thus all material of cellular origin gives a response with the ATP bioluminescence method (Green et al. 1999), both microbes and other organic matter in the manure soil probably resulted in its high ATP content. Furthermore, the reproduction of microbes on the surface both after soiling and after cleaning may have affected the ATP results. However, with the present experimental setup it was not possible to analyse in more detail the effects of different components of the soil on the ATP results. In general it is known that one ATP molecule produces one photon of light, and thus the light intensity from the reaction is proportional to the amount of ATP in the sample (Green et al. 1999). The ATP method is normally used for detection of surface contamination (Davidson et al. 1999, Storgårds 2000, Champiat et al. 2001, Wirtanen et al. 2002, Redsven et al. 2007), and on the basis of these studies from other fields of application, the method was tested on agricultural surfaces and soils in the present study.

Using the biochemical ATP method the differences between the non-coated concrete and coated concretes were less clear than in the radiochemical study. This is probably due to the disadvantage that the biochemical ATP determination method does not take into account the amount of absorbed soil. The biochemical ATP method is sensitive to organic contaminants and therefore useful in determination of cleanability at sites or rooms with relatively high hygienic requirements, e.g. in milk rooms.

In the present study the oil-containing radiochemical model soil was removed the least efficiently and the inorganic particle soil containing chromium oxide the most efficiently. These results from concrete materials in the radiochemical study were mainly consistent with the results of our earlier studies concerning plastic and ceramic materials (Määttä et al. 2007a,b). By examining the cleanability and surface properties of laboratorymade and commercial surface materials intended for use in cattle barns it was possible to select some promising surfaces for a pilot study in a cattle barn. The materials selected for the pilot study were epoxy-, polyurethane- and acrylic coatings for floorings, and in addition the traditional concrete and polyester coating were selected for the feeding table. 


\section{Määttä, J. et al. Surface materials for use in cattle barns}

\section{Conclusions}

In general, coatings improved the cleanability of the flooring materials according to the results of the radiochemical determination method. In other words, polyester, acrylic and polyurethane coatings were cleaned the most efficiently and the cleanabilities of the non-coated concretes were poorest. In general, the epoxy-coated concrete was cleaned the most efficiently from the labelled natural soils, manure and feed. According to both radiochemical measurements, the cleanability of the non-coated concrete including inorganic sealant from manure soils was good. The cement-based joint materials were cleaned better than the joint containing epoxy especially from the inorganic particle soil, but less efficiently from the oil model soil and labelled feed soil. According to both contact angle measurements and topographic measurements, the coatings sealed the porous surfaces.

In the present experimental setup, both the radiochemical and the biochemical ATP determination methods were suitable for examining cleanability of concrete materials from agricultural soils. Only the radiochemical determination provides detailed quantitative results, but its use is limited to laboratory studies. A correlation was observed between the results of cleanability of radiochemical oil model soil and the ATP amount of feed soil after the first cleaning.

Acknowledgements.Financial support from the Ministry of Agriculture and Forestry in Finland (project Easy-toclean surfaces in farm buildings) and the Finnish Cultural Foundation is gratefully acknowledged. DeLaval, Nanten, Suomen Elektrodi and Lujabetoni are acknowledged for providing surface materials. Freudenberg Household Products is acknowledged for providing the mop cloths, Farmos for providing detergents and VWR International Oy for providing the ATP accessories.

\section{References}

ACI 515.1R-79. 1985. A guide to the use of waterproofing, dampproofing, protective, and decorative barrier systems for concrete. In: ACI manual of concrete practice 1988, Part 5. American concrete Institute, USA. $44 \mathrm{p}$

Aycicek, H., Oguz, U. \& Karci, K. 2006. Comparison of results of ATP bioluminescence and traditional hygiene swabbing methods for the determination of surface cleanliness at a hospital kitchen. International Journal of Hygiene and Environmental Health 209:203-206.

Barbucci, A., Delucchi, M. \& Gerisola, G. 1997. Organic coatings for concrete protection: liquid water and water vapour permeabilities. Progress in Organic coatings 30: 293-297.

Baxter, S. 1984. Intensive Pig Production: Environmental Management and Design. Granada Publishing Ltd, Great Britain. 588 p.

Benzarti, K., Perruchot, C. \& Chehimi, M.M. 2006. Surface energetics of cementitious materials and their wettability by an epoxy adhesive. Colloids and Surfaces A: Physicochemical Engineering Aspects 286: 78-91.

Bertron, A., Duchesne, J. \& Escadeillas, G. 2005. Attact of cement pastes exposed to organic acids in manure. $\mathrm{Ce}$ ment \& Concrete Composites 27: 898-909.

Champiat, D., Matas, N., Monfort, B. \& Fraass. 2001. Applications of bioluminescence to HACCP. Luminescence 16: 193-198.

Davidson, C.A., Griffith, C. J., Peters, A.C. \& Fielding, L. M. 1999. Evaluation of two methods for monitoring surface cleanliness - ATP bioluminescence and traditional hygiene swabbing. Luminescence 14: 33-38.

De Belie, N., De Blaere, B. \& Verschoore, R. 1996. Compounds aggressive to concrete floors in pig houses. Landwards 51: 22-26.

De Belie, N., Lenehan, J.J., Braam, C.R., Svennerstedt, B., Richardson, M. \& Sonck, B. 2000. Durability of building materials and components in the agricultural environment, part III: concrete structures. Journal of Agricultural Engineering Research 76: 3-16.

Engström, S. \& Bäckström, K. 1987. Ellipsometry as a tool to study detergensy at hard surfaces. Langmuir 3: $568-574$.

Green, T.A., Russel, S.M. \& Fletcher, D.L. 1999. Effect of chemical cleaning agents and commercial sanitizers on ATP bioluminescence measurements. Journal of Food Protection 62: 86-95.

Hörndahl, T. 1995. Slitstyrka och halksäkerhet hos golv I djurstallar. Inverkan av material och utförand. (Wearing quality and prevention of slipperiness on solid floors in animal houses. Influence of materials and performance). Specialmeddelande 220, Sveriges Lantbruksuniversitet, Institutionen för Jordbrukets Biosystem och Teknologi, Lund, Sweden. 49 p.

Jokelainen, A. \& Uusi-Rauva, A. 1976. Reinigung von Linoleum- und PVC-Bodenbelägen von radioaktivem Partikelschmutz. Seifen-Öle-Fette-Wachse 72: 443-445.

Kemppainen, M., Lahtinen, S.T., Suontamo, T., Alen, R. \& Sjöberg, A.-M. 2002. Cleanability of ceramic tile grout materials. Tenside Surfactants Detergents 39: 8-12.

Kuisma, R., Pesonen-Leinonen, E., Redsven, I., Ylä-Outinen, I., Hautala, M. \& Sjöberg, A.-M. 2003. A practical testing procedure for floor coverings: cleanability and resistance to chemical and mechanical wear. Tenside Surfactants Detergents 40: 25-30.

Kuisma, R., Pesonen-Leinonen, E., Redsven, I., Reunanen, E., Kymäläinen, H.-R., Sjöberg, A.-M. \& Hautala, M. 
Vol. 17 (2008): 210-226.

2005. Soiling tendency of worn, plastic flooring materials related to their surface topography. Tenside Surfactants Detergents 42: 154-162.

Kymäläinen, H.-R., Määttä, J., Puumala, M., Kaustell, K.O., Mattila, T., Joutsen, B.-L., Kuisma, R., Hurme, K.-R., Uusi-Rauva, A. \& Sjöberg, A.-M. 2008. A laboratory study of the effect of coating on cleanability of concrete flooring for use in piggeries. Biosystems Engineering 99: 88-98. In press.

Larson, E.L., Allison, E.A., Gomez-Duarte, C., Lin, S.X., Lee, L., Della-Latta, P. \& Lindhardt, C. 2003. Bioluminescence ATP monitoring as a surrogate marker for microbial load on hands and surfaces in the home. Food Microbiology 20: 735-739.

Larsson, K. 2000. Rengöring av svinstall. (Cleaning of pighouses) JTI-rapport Lantbruk \& Industri Nr 266, Jordbrukstekniska institutet, Uppsala, Sweden. 49 p.

Määttä, J. Koponen, H.-K., Kuisma, R., Kymäläinen, H.-R., Pesonen-Leinonen, E., Uusi-Rauva, A., Hurme, K.-R., Sjöberg, A.-M., Suvanto, M. \& Pakkanen. T.A. 2007a. Effect of plasticizer and surface topography on the cleanability of plasticized PVC materials. Applied Surface Science 253: 5003-5010.

Määttä, J., Piispanen, M., Kuisma, R., Kymäläinen, H.-R., Uusi-Rauva, A., Hurme, K.-R., Areva, S., Sjöberg, A.-M. \& Hupa, L. 2007b. Effect of coating on cleanability of glazed surfaces. Journal of the European Ceramic Society 27: 4555-4560. In press.

Nilsson, C. 2005. Use of concrete for floors in livestock buildings. In: Concrete for a sustainable agriculture, Agro-, aqua and community applications. Proceedings for the Vth International Symposium on 5-8 June, 2005. San Lorenzo de El Escorial, Spain. p. 25-32.

Ohlson, H. \& Wäänänen, M. 1971. Determination of soiling of flooring materials by using artificial radioactive soils. The State Institute for Technical Research, Tiedotus. Sarja III-Rakennus 160. Helsinki. VTT Offsetpaino. p.38.

Pelletier, F., DeFoy, C., Marquis, A., Godbout, S., Joncas, R., Gagne, R. \& Masse, D. 2002. Effects of different concrete types on gas, odour emissions and sanitation of swine buildings. In: Concrete for a sustainable agriculture, Agro-, aqua and community applications. Proceedings for the IVth International Symposium on 21-24 April, 2002. Ghent, Belgium. p. 287-294

Pesonen-Leinonen, E., Redsven, I., Kuisma, R., Hautala,
M. \& Sjöberg, A.-M. 2003. Cleaning efficiencies of mop cloths on floor coverings. Tenside Surfactants Detergents 40: 80-86.

Pesonen-Leinonen, E., Redsven, I., Neuvonen, P., Hurme, K.-R., Pääkkö, M., Koponen, H.-K., Pakkanen, T.T., Uusi-Rauva, A., Hautala, M. \& Sjöberg, A.-M. 2006. Determination of soil adhesion to plastic surfaces using a radioactive tracer. Applied Radiation and Isotopes 64: 163-169.

Poulis, J.A., de Pijper, M., Mossel, D.A.A. \& Dekkers, P.Ph.A. 1993. Assessment of cleaning and disinfection in the food industry with the rapid ATP-bioluminescence technique combined with the tissue fluid contamination test and a conventional microbiological method. International Journal of Food Microbiology 20: 109-116.

Puumala, M. \& Lehtiniemi, T. 1993. Betonit ja muovit navetan lattiamateriaaleina. (Concrete and plastic as floor materials in barns). Vakolan tutkimusselostus 67 , MTT, Vihti, Finland. 85 p.

Redsven, I., Kymäläinen, H.-R., Pesonen-Leinonen, E., Kuisma, R., Ojala-Paloposki, T., Hautala, M. \& Sjöberg, A.-M. 2007. Evaluation of a bioluminescence method, contact angle measurements and topography for testing the cleanability of plastic surfaces under laboratory conditions. Applied Surface Science 253: 5536-5543.

Small, A., James, C., Purnell, G., Losito, P., James, S. \& Buncic, S. 2007. An evaluation of simple cleaning methods that may be used in red meat abattoir lairages. Meat Science 75: 220-228.

Storgårds, E. 2000. Process hygiene control in beer production and dispensing. Academic dissertation. VTT Publications 410. Technical Research Centre of Finland, Espoo 105 p. + app. 66 p.

Sundahl, A.-M. 1974. Byggnadsmaterial I djurstallar, Nedsmutsing-rengöring. (Building materials in animal houses, Soiling - cleaning). Sveriges Lantbruksuniversitet, Institutionen för landbrukets byggnadsteknik, Aktuellt 211, Teknik, Uppsala, Sweden. 33 p.

Wirtanen, G., Langsrud, S., Salo, S., Olofson, U., Alnås, H., Neuman, M., Homleid, J.P. \& Mattila-Sandholm, T. 2002. Evaluation of sanitation procedures for use in dairies. VTT Publications 481. Technical Research Centre of Finland, Espoo. 96 p. + app. 43 p.

Zhang, G., Strøm, JS., Blanke, M. \& Braithwaite, I. 2006. Spectral signatures of surface materials in pig buildings. Biosystems Engineering 94: 495-504. 


\title{
AGRICULTURAL AND FOOD SCIENCE
}

Määttä, J. et al. Surface materials for use in cattle barns

\section{SELOSTUS}

\section{Laboratoriotutkimus navetan uusista ja perinteisistä pintamateriaaleista}

\author{
Jenni Määttä, Hanna-Riitta Kymäläinen, Maarit Hellstedt, Riitta Mahlberg, Risto \\ Kuisma, Liisa Salparanta, Mia Löija, Asaye Talibachew, Kaj-Roger Hurme, Antti \\ Uusi-Rauva, Anne-Christine Ritschkoff, Anna-Maija Sjöberg
}

Helsingin yliopisto, MTT ja VTT

\begin{abstract}
Tutkimuksen tavoitteena oli selvittää seitsemän erilaisen betonimateriaalin koostumuksen ja pinnoitteen vaikutus niiden puhdistuvuuteen. Lisäksi tutkittiin kolmea erilaista saumausainetta. Pintaominaisuudet selvitettiin kontaktikulmamittarilla, optisella profilometrillä ja pyyhkäisyelektronimikroskoopilla (SEM). Puhdistuvuutta mitattiin radiokemiallisilla määritysmenetelmillä sekä biokemiallisella menetelmällä, joka perustuu ATP:n (adenosiinitrifosfaatti) määrän mittaamiseen. Likoina käytettiin laboratoriotutkimuksiin kehitettyjä mallilikoja ja luonnollisia maatalouden likoja. Sekä radiokemialliset määritysmenetelmät että ATP-menetelmä soveltuivat maatilalikojen puhdistuvuuden sekä likajäämien määrittämiseen pinnoilta. Radiokemialliset menetelmät antavat kvantitatiivisen tuloksen, mutta niitä voidaan käyttää ainoastaan laboratorio-olosuhteissa.
\end{abstract}

Pinnoittamattomien ja pinnoitettujen betonien sekä saumausaineiden kontaktikulmat erosivat toisistaan. Karheusarvojen ja SEM-kuvien perusteella saumausaineet olivat karheimpia pintoja ja pinnoittaminen tasoitti betonipintoja. Radiokemiallisten puhdistuvuuskokeiden mukaan pinnoittaminen paransi myös puhdistuvuutta. ATP-menetelmällä ainoastaan tiivistetty betoni erosi muista materiaaleista; se puhdistui lantaliasta parhaiten ensimmäisen puhdistuksen jälkeen. Epoksipohjainen saumausaine puhdistui öljymäisestä malliliasta parhaiten, kun saumausaineita verrattiin keskenään. Kokonaisuutena polyesteri-, akryyli- ja polyuretaanipinnoitetut näytteet puhdistuivat parhaiten. Pinnoittamista suositellaan tiloihin ja pinnoille, joilta vaaditaan hygieenisyyttä, esimerkiksi ruokintapöydille ja lypsyasemille. 